"Demarketing strategy to develop perceived product reputation: applications in three distinct environments"

AUTHORS Solly Matshonisa Seeletse

Solly Matshonisa Seeletse (2016). Demarketing strategy to develop perceived

ARTICLE INFO product reputation: applications in three distinct environments. Problems and Perspectives in Management, 14(4-1), 230-235. doi:10.21511/ppm.14(4-

1).2016.12

DOI http://dx.doi.org/10.21511/ppm.14(4-1).2016.12

RELEASED ON Friday, 23 December 2016

JOURNAL

"Problems and Perspectives in Management"

FOUNDER

LLC "Consulting Publishing Company "Business Perspectives"
NUMBER OF REFERENCES

0

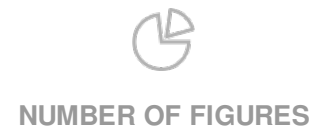

0

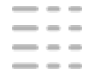

NUMBER OF TABLES

0

(C) The author(s) 2022. This publication is an open access article. 


\title{
Demarketing strategy to develop perceived product reputation: applications in three distinct environments
}

\begin{abstract}
This paper illustrates 'demarketing' and its uses to improve product image in the customers' viewpoints. Three events stimulated the investigations. First, a leading political party lost local municipal elections in a large South Africa metropolitan. Second, a reputable soccer club lost many fans to other teams. Thirdly, a local confectionary lost clients. Investigations took place in the three settings (soccer, politics and confectionary business). The respondents were known clients or fans of the original entities, who had defected to rivals. A questionnaire was used to collect data. The entities apparently ignored the services promised to clients. Despite them being dissimilar entities, similarities occurred in the way they lost favor with their clients. The study identified demarketing as a common factor. Demarketing was applied by the rivals, and was imbedded in their policies. People and entity representatives' used demarketing strategies to lure clients. The paper recommends that demarketing should be applied to control the market. Also, it recommends that agile competitors should augment normal marketing with demarketing to optimize marketing results.
\end{abstract}

Keywords: demarketing strategy, demand, perception, product quality.

JEL Classification: D47, M14, M31, M37.

\section{Introduction}

Consumption habits and behaviors affect marketing perceptions and purchasing response. Astute marketers use these traits to increase individual perceptions to improve consumer behavior. According to Alsamydai (2015), these consumer habits and patterns are a source of concern to relevant agencies, many of which attempt different ways to sway individual and customer behavior to the direction that serves the community and the economy. A method known as demarketing is one such strategy. Demarketing is anti-marketing done in the attempt to decrease consuming tendencies towards a product. It is a process of costumer persuasion to change their attitudes towards products (including services) representing deterring consumption permanently or temporarily (Moore, 2005). It is usually an aspect of social marketing with the philosophy to create a healthier environment for the community by determining the consumption of a certain product. Basically, demarketing limits demand or consumption of a certain product. It is a marketing technique complementing ordinary marketing. This paper focuses on the effects of employing demarketing strategies to benefit situations and also improve product quality.

The main purpose of this paper was two-fold. Firstly, it examined factors that influence the demarketing strategy on improving product reputation in customer's minds. Secondly, it intended to determine the extent to which each of these factors wield that influence.

(c) Solly Matshonisa Seeletse, 2016.

Solly Matshonisa Seeletse, Department of Statistics \& Operations Research, Sefako Makgatho Health Sciences University, Gauteng Province, South Africa.

\section{Literature review}

1.1 Demarketing concept. Bradley and Blythe (2013) define demarketing as a deliberate effort by marketers to decrease demand for a product by using the same tools and techniques which are normally used to increase demand. Dominic, Warnaby and Dharni (2011) view demarketing as enterprises' efforts aimed at reducing the demand for some products. Wall (2007) defines demarketing as ways to convince customers to change their attitudes and behaviors regarding certain products. Shilpla et al. (2007) define demarketing as an attempt to decrease certain types of customers to consume a certain product either for a limited time, or permanently. Beeton and Pinge (2003) define demarketing as the act of discouraging consumption or use of a specific product. This paper therefore, describes demarketing as an attempt to reduce demand on a certain product due to (among others):

- Incapability and/or unwillingness to provide large amounts of the product;

- Rationalize the consumption of some highpriced products considered a strain on national economy;

- Reduce consumption of products considered dangerous to public health and personal health, or even the irrational consumption of some home products or nutrients, this direction helps limit product consumption of endangered products;

- Enhance product quality perceptions in the public eye; and

- Increase perceived product value.

1.1.1. Demarketing strategy. Demarketing requires changes of prevailing orientations for the usual marketing (Mossadegh \& Mouser, 2012). Also, there should be a change in the work environment 
and its nature, directing the effort to decrease the demand to reduce customers' willingness to buy. This is the reverse to usual marketing. Demarketing can be used to create awareness in individuals regarding the necessity of economy in irrational consumption, such as water and electricity wastages. This approach in demarketing is a social and cultural change to show a transition of social values and habits and consuming patterns away from overconsumption and towards limited consumption.

Three different demarketing strategies are general demarketing, selective demarketing and ostensible demarketing (Dominic et al., 2011; Bradley \& Blythe, 2013; Rudaina, 2014):

- General demarketing is necessary when a company wants to reduce total demand.

- Selective demarketing is used when a company wants to discourage the demand coming from certain customer levels.

- Ostensible demarketing aims decrease the demand on a specific product for a limited time with the intention of increasing its price in the future and create the image of missing the product in the market, creating an impression in the customer's mind regarding the product quality making it valuable and worthy to be had.

Several classic tools of demarketing to reduce demand were suggested (Gupta, 2014). These include limiting advertising expenditures for the product; decreasing sales promotion expenditure; escalating the price and other conditions of sale; and limit the number of distribution outlets.

Alsamydai and Rudaina (2005) enlighten that perception in the behavior area is interpreted through two factors. First is the impulsive direction of external and internal physiological activity of the individual and customer. Second is the choosing of information. Individuals and customers are free to choose certain information and to discard unknown or mysterious information. Consequently, the customer or the individual behavior and satisfaction are affected by their level of perception.

1.1.2. Improving product reputation in customer's mind. Customers' perceptions of product quality are affected by marketing and demarketing factors. One demarketing tool is to increase product price where the relationship between price and quality is not justifiable. Generally, higher prices indicate product quality. Thus, decreasing offer could be effected by making the product unavailable in the market. This might indicate the rarity of the product. In the customer's mind this could represent the increase in the product's value and quality. In addition, limited distribution renders the product unavailable on the wider scale. The narrow advertising might reduce the incidence of the customer remembering the product. In general though, these factors lead to increasing perception of the product value, which means that in the customer's mind the product is more worthy to purchase.

1.2. Demarketing experiences. Moore (2005) studied demarketing and its strategies on smoking effects. The effect of demarketing was to lower the unhealthy, personally and socially damaging phenomenon of smoking. Bourdean, Brady and Cronin (2006) examined the drivers of risky behaviors such as smoking among the economically deprived. Darman (2008) also focused on demarketing's role in controlling and limiting smoking. Lee et al. (2004) studied the smoking phenomenon and its effect on African Americans in the United States of America. These studies demonstrated that demarketing can indeed reduce the product demand.

In countries such as Brazil, Gaza, Jordan, Iran and Iraq, demarketing was applied on electricity and water consumption for several reasons, such as management and preservation using strategies that include price increases (Rudaina, 2014; Salman, 2015). The studies concluded that demarketing decreased consumption by as much as $46 \%$.

While general and selective demarketing strategies are useful, consumer behavior often benefit immensely from ostensible demarketing. British Airways used ostensible demarketing in a campaign named 'Britons Don't Fly' (Bradley \& Blythe, 2013). The entire exercise of demarketing resulted in marketing enhancement of British Airways in aspects of marketing and quality perceptions. Another experience of ostensible demarketing came from the example of New Coke (Clifford, 2009). According to Haig (2013), demarketing was used to create the appearance of a strategic marketing withdrawal with the express intention of boosting a declining brand (Haig, 2013). The use of ostensible demarketing strategy improved product image in the customers' perception through the employment of specific tools like decreasing offer, increasing price, narrow advertising, and limited distribution, among others.

\section{Study model}

The demarketing strategy model is designed based on several literature sources (Gupta 2014; Rudaina, 2014). Demarketing is a concept, philosophy, and a practice that has upgraded from being an activity only of business organizations, to a distinctive place in the economic life of society. This is indicated by most innovative creative activities containing marketing as a vital component. Demarketing has assisted countless organizations to reconsider their 
marketing aims. One demarketing benefit is looking at value and quality instead of mass sales. Altai et al. (2006) exhibit this benefit by explaining that organizations which adopt the concept achieve abundant successes by focussing on the 4-Cs (customers value, cost to the customer, convenience and communication). Alsamydai (2014) also indicates that the theory is based on customer behavior theories which draw upon the social and behavioral sciences. Darman (2008) views the demarketing concept as the activities for establishing the link between the project and the market, as well as philosophy and ideology that controls the different activities.

Demarketing's primary role is to decrease customers by rationalizing and guiding them on some products through the cancelling of the unnecessary consumption. It guides the customer towards products that do not harm his/her health or that harm society, it improves product image in the customers' minds, and it makes the product desirable to the customer. According to Wamaby (2011), demarketing involves decreasing the product's consumption, and is the marketing aspect that deals with discouraging customers in a certain class. Demarketing is usually applied in pursuit of the marketer's task to shape demand to conform with long-term marketing objectives.

\section{Methodology}

3.1. Research design. The design was qualitative. This paper aimed to establish reasons for losses of fans or clients, and mainly focusing on the impact of demarketing strategy on improving product reputation in customer's minds. More specifically, the research examined factors of influence in changing favor and extent to which each of these factors influence the demarketing strategy on improving product reputation in customer's minds.

3.2. Data collection tool. The empirical work depended on questionnaires for data collection. The questionnaire was piloted, validated and corrected for quality and reliability. Four main topics covered in the questionnaire were decreased offer, increased detriment, limited distribution and narrow advertising. Each topic consisted of component items forming the main topic. A five-point Likert scale was used for the items.

3.3. Study population. Three strata forming the study population were used for this paper. The first stratum was made of publicly known soccer supporters of a historically top soccer club in South Africa who had defected to newly established and promoted ones. The query followed Sweeney's (2008) counselling of using fans to comfort and support a besieged club. The second one consisted of former supporters of a historical political party since democracy, who were also known former recruiters for the party they left. This stratum benchmarked Smilner's (2010) questioning of the perceivable undesirable changes after several years of a party's perceived reputation. The third one consisted of former regular customers of a confectionary in a Pretoria township. Stock and Balachander's (2005) model was venerated on this stratum to explore the changes of a previously likeable product that all of a sudden was dwindling in sales.

3.4. Sample. Few identified persons among the groups identified were selected for inclusion in the sample. They were recruited to participate and help to identify others in their groups. Through snowballing, new respondents were recruited. The sampling method was thus multistage. Multistage sampling of two stages was conducted by starting with purposive sampling that was augmented using snowballing.

3.5. Data collection. The questionnaires were adapted to suit the languages and jargon used in the trades. Respective piloting also took place using MBA students of a local business school. Study questionnaires were then distributed to the first groups of respondents who took more questionnaires to distribute on behalf of the researcher to the willing respondents in their trades. Six hundred questionnaires were prepared and two hundred were distributed in each of the trades.

3.6. Data analysis. Scaling is vital in research (Malhotra et al., 2004). Furthermore, the measure from the Likert scale was measured based on the total of five (5). Statistical methods were used to analyze the data. These were frequency analysis, descriptive analysis, Pearson correlation matrix and t-test. The percentages were used to measure effectiveness.

\section{Results}

Soccer respondents were 152 , political party ones were 177 , and confectionary clients were 143 . The table below displays the results.

4.1. Measurement results. The statistical measures appear in the next presentations.

Table 1. Responses of strata

\begin{tabular}{|l|c|c|c|}
\hline \multicolumn{1}{|c|}{ Frequency } & Soccer & Politic & Confect \\
\hline Ones & 2 & 3 & 3 \\
\hline Twos & 3 & 5 & 3 \\
\hline Threes & 7 & 22 & 9 \\
\hline Fours & 131 & 119 & 115 \\
\hline Fives & 9 & 28 & 13 \\
\hline Mean & 3.93 & 3.92 & 3.92 \\
\hline Std dev & 0.55 & 0.74 & 0.65 \\
\hline CV & 0.13995 & 0.18878 & 0.16582 \\
\hline Measure & $78.6 \%$ & $78.4 \%$ & $78.4 \%$ \\
\hline
\end{tabular}




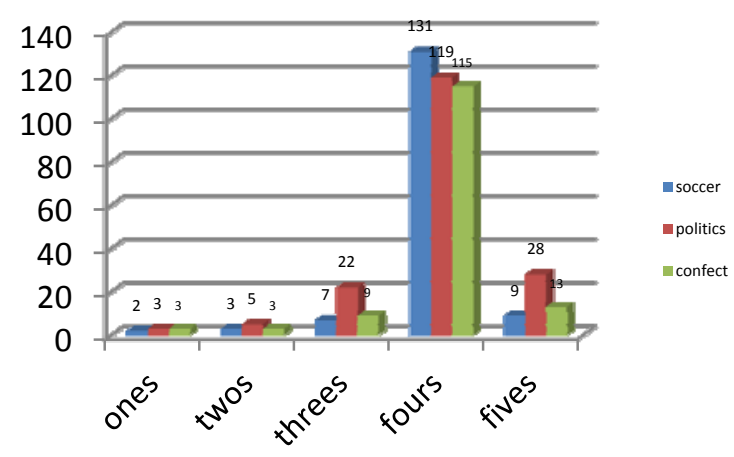

Fig. 1. Comparison of category responses

Soccer fans were influenced at $78.6 \%$, while political party and confectionary influences to rivals were at $78.4 \%$. All of them were very high with soccer sample as the highest. Also, the soccer group was the most stable with lowest coefficient of variation (CV) being only 0.14 , or $14 \%$.

There were very few respondents who had not been influenced by demarketing, shown by measures 'ones' and 'twos'. Those at ' 4 ' were in the majority, and this is $80 \%$ demarketing influence on the respondents. The seriousness of the influence is shown by existences of demarketing at maximum level, at 5 , or $100 \%$. The modal occurrence was at $80 \%$ (fours) for all the strata.

Table 2. ANOVA

\begin{tabular}{|l|c|c|c|c|c|c|}
\hline $\begin{array}{l}\text { Source of } \\
\text { Variation }\end{array}$ & SS & df & MS & F & P-value & F crit \\
\hline $\begin{array}{l}\text { Between } \\
\text { groups }\end{array}$ & 124.133 & 2 & 62.067 & 0.024 & 0.977 & 3.839 \\
\hline $\begin{array}{l}\text { Within } \\
\text { groups }\end{array}$ & 31283.6 & 12 & 2606.97 & & & \\
\hline
\end{tabular}

The hypothesis on which ANOVA (analysis of variance) table is based is that the means of the three variables (soccer, politics and confectionary trades) are equal. This is to compare if the influences of demarketing in the trades were the same. The observed test statistic given by $\mathrm{F}(\mathrm{F}=0.024)$ is lower that the critical $F(F=3.839)$ value. The hypothesis of equality cannot be rejected and this leaves no doubt that the demarketing influence was equally highly effective in the three cases.

Table 3. Correlation matrix

\begin{tabular}{|l|c|c|c|}
\hline & soccer & politics & confect \\
\hline Soccer & 1 & & \\
\hline Politics & 0.985 & 1 & \\
\hline Confect & 0.999 & 0.990 & 1 \\
\hline
\end{tabular}

The three variables are also highly correlated. This is despite the fact that the three variables are not causally related and are basically independent of each other. A coincidence of the high correlation could be reflecting a poor trait about the greater community.
4.2. Verbatim results. The issues that repeated numerously and overbearingly were that the parties involved were arrogant. In the soccer responses, the complaints were that management did not care about fans and the formal fan clubs. Apparently, management had released high performing coaches and replaced by mediocre ones who brought poor play, undesirable styles and poor performances (unusual many losses of games), no trophies and low league rankings. Apparently, losses also occurred to some soccer clubs that the club of study focus had never lost to. The political party was also said to be corrupt, and arrogantly protecting the law against the culprits. In addition, the party also imposed local leaders on communities when people had made their choices. The level of service delivery was low as well, not justifying the imposed leaders. On the confectionary, the prices had gone to high up but no value added to the products.

In all these three cases, the competitors were doing what the people/customers wanted from their original favorites. The changes in favouritism occurred because the competitors were delivering much closer to what the clients wanted.

\section{Discussion}

Demarketing affected the three entities immensely, to their detriments. The example shows also that demarketing is not limited to business, but to social and political problems as well, among others. The demarketing undertakings were unplanned in some instances, while in others the competitors capitalised on the weaknesses and strengthened their visibilities which they knew were the desired aspects of customers.

The three entities are diverse, and with no possible relationships or dependencies. However, they are highly correlated. The verbal responses indicated arrogance to be common in two of the trades (soccer and politics), and this affects business. This shows how poor personal traits can be detrimental to business and management.

Demarketing was shown to be influential regardless of whether it is planned or mechanical. This shows that for the organizations that know about this concept can use it to their advantage whether they want to increase or decreases their clients. Those that do not know it can be damaged by unconscious practices that worry customers.

The fact that personality traits can be embedded into business practices can be dangerous if the traits are not appealing to people. The main problem is that such traits do not occur from a plan, but tend to impose themselves. In the case of this paper, negative aspects showed to influence the 
negative results for the entities studied. The respondents were clearly mentioning the victors in the business competition, in which rival competitors in each of the three trading entities lost their clients in separate manifestations.

The paper demonstrated the colossal effect of demarketing strategy on a vibrant issue of improving business reputation in customers' minds, regardless of the nature of the trade in question. The effects can be increased by consciously planning. Furthermore, these effects can be increased further, or even maximized when the recipient is not aware of the concept or its practice.

The first point in the defining of demarketing (section 2.1) seems obvious in this study which is 'Incapability and/or unwillingness to provide large amounts of the product'. In the political party and soccer cases, both unwillingness and incapability seemed to apply. Deployment in both cases of incapable leaders who refused to listen to people or fans was the weakness of the managements in both cases. In the confectionary case business it seemed to be relative incapability when compared with competitors. The results in all the cases led to the results in the points 3 to 5 , which were 'reduction in consumption of competitors' products'; 'increase in quality in the new entrants' and 'increased perception on the values of offering by the new entrants'. The political parties pursued demarketing deliberately in their campaigns, but in many cases the losing parties applied it unconsciously through their arrogance and ignoring their markets, which was basically demarketing conducted unintentionally.

Moreover, the demarketing which took place was general demarketing, which was needed to reduce total demand from rivals. Selective demarketing was not used since discouraging demand from competitors was for all the markets and not selected ones. Also, efforts could not have been ostensible demarketing as discouraging demand was not for a limited period.

Lastly, on the purpose of this paper, the pertinent factors that influenced demarketing in the customer's minds were arrogance, failure to provide market desirables, and relative weakness compared to rivals. The extent to which these factors could wield the influence can be maximal, as shown by losing the election and markets if the political party collapses and the confectionary business fails due to lack of markets.

\section{Recommendations}

- Managers and users of human markets should always be pleasurable to avoid unplanned offending people without realising it. This is to attempt including positive human traits in business to offset adverse business effects;

- Marketers should incorporate demarketing strategies in their business management to control the market;

- Demarketing should be integrated in aspects of daily lives to improve people behaviors and the qualities of life; and lastly,

- Demarketing should be integrated into the general concept of marketing.

\section{Conclusion}

The results of this paper show that demarketing is a business concept with huge potential to change live patterns to improve quality of live. The traders who satisfied people with the way they treated them showed to have attracted clients from competitors. The concept was tested on various environments from diverse industries. The investigations were in both public and private domains. Also, management and lower categories were equally detrimental to the entities involved, as each one represented the environments with the behaviors they display.

Further, demarketing can change people's attitudes and behaviors when it is understood. The reflections of the losing parties show that their arrogance was their unique losing point. If they conduct introspection they can be informed of their bad ways. Their response should be to change their behaviors. Hence, bad behaviors can be discouraged and code of conduct is more likely going to lean towards altruism.

Moreover, human manners and business manners are both influential to business success or failure. Sensitive customers are the ones more responsive to demarketing that is influenced by behaviors of the owners or their stakeholders.

\section{References}

1. Alsamydai, M.J. (2015). The impact of ostensible demarketing strategy on improving product reputation in customer's minds. International Review of Management and Business Research, 4(4), pp. 973-988.

2. Alsamydai, M.J. \& Rudaina, O.Y. (2005). Consumer behavior: the entrance to a quantitative and analytical, $2^{\text {nd }}$ edition. Amman: Al-Zaytooneh University of Jordan. 
3. Alsamydai, M.J. (2014). Adaptation of the Technology Acceptance Model to the use of mobile banking services. International Review of Management and Business Research, 3 (4), pp. 2010-2028.

4. Altai, H, Alsamydai, M., Alalak, B., Alqrem, A. (2006). The scientific foundations of modern marketing. AL Yazori of Publishing.

5. Beeton \& I. Pinge, (2003). Casting the holiday dice, demarketing gambling to encourage local tourism. Current Issues in Tourism Journal, 6(4), pp. 499-500.

6. Bradley, N. \& Blythe, J. (2013). Demarketing. New York: Routledge.

7. Bourdean, B.L., Brady, M.K. \& Cronin, J.J. (2006). A new frontier in the battle against smoking: An exploratory investigation of low-income adult smokers, Journal of Nonprofit \& Public Section Marketing, 16, pp. 123-147.

8. Clifford, S. (2009). Coca-Cola deleting “classic” from coke label. New York Times, $31^{\text {st } J a n u a r y . ~}$

9. Darman, S.S. (2008). The role of demarketing in the reverse control or curb smoking. Iraqi Journal Administrative Sciences, 24: 1-29.

10. Waranaby, G. (2011). Demarketing places: Rational and strategies. Journal of Marketing, 27 (1-2): 124-142.

11. Gupta, R.K. (2014). Demarketing: tool social good. MBA dissertation, Aravali Institute of Management, Jodhpur, Rajasthan, India.

12. Haig, M. (2013). Brand failures: the truth about the 100 biggest branding mistakes of all time. London: Kogan Page Publishers.

13. Lee, D., Boh, D.C. \& Burns, J. (2004). The marketing and demarketing of tobacco product to low-income African American. Health Marketing Quarterly, 22(2), pp. 1-68.

14. Malhotra, N.K. (2004). Marketing research: an applied orientation, $4^{\text {th }}$ edition. Upper Saddle, River, N.J.: Prentice Hall.

15. Dominic, M., Warnaby, G. \& Dharni, S. (2011). Demarketing places: rationales and strategies. Journal of Marketing Management, 27 (1 \& 2), pp. 12-142.

16. Moore, S.R. (2005). The sociological impact of attitude toward smoking secondary effect of the demarketing of smoking, Journal of Social Psychology, 145(6), pp. 703-718.

17. Mossadegh S.N. \& Mouser, H.A. (2012). The possibility of applying demarketing strategy to rationalize electricity. Journal of Economics and Administrative Sciences, 80(24), pp. 145.

18. Rudaina, O.Y. (2014). Measuring the effectiveness of demarketing in influencing consumer behavior of individuals, International Journal of Business Management \& Research, 4(5), pp. 31-43.

19. Salman, F.M. (2015). Effect of demarketing on rationalization of electricity consumption in Jordan, Thesis for Master's degree in Marketing, Zarqa University, Jordan, P8-20.

20. Shilpla, D., Ajay P., Sreedhar, D., Manthan I., Virendra, S. \& Ligade, N. (2007). Demarketing of injurious consumption: An Indian scenario. Demarketing of Injurious, Wednesday, $25^{\text {th }}$ July.

21. Smilner S.R. (2010). Dressing fancy: after 96 years Hemz Salad cream gets a new flavour. The Guardian, $1^{\text {st }}$ September.

22. Stock, A. \& Balachander, S. (2005). The making of a 'hot product': A signalling explanation of marketer's scarcity strategy. Management Science, 51(8), pp. 1182-1192.

23. Sweeney, M. (2008). Cadbury calls on Wispa fans for ad help. The Guardian, 5 November.

24. Wall, A.P. (2007). Government 'demarketing' as viewed by its target audience. Marketing Intelligence \& Planning, 25 (2), pp. 123-125.

25. Wamaby, G. (2011). Rationales and strategic Dominic Medway, Journal of Marketing. Management, 27 (1-2), pp. 124-142. 